\title{
The Global Contributions of Ancient Chinese Philosophy-Aesthetics
}

\author{
GU Zu-zhao \\ Anhui University, Hefei, China
}

\begin{abstract}
This article argues that ancient Chinese Philosophy-Aesthetics, as an important Other from the West, has made global contributions which are of major significance to the future theoretical building. Most Western scholars and some modern Chinese scholars so far have failed to pay attention to these critical achievements. This article intends to expound the global contributions of Chinese aesthetics in three ways. One is Laozi's interpretative mode of grandeur, another is Zhuangzi's notion of mutual generative aesthetics and the other Mencius's view of philosophical beauty.
\end{abstract}

Keywords: interpretative mode, conceptual system, the mutual generation of trinity and plurality, philosophical beauty

The major paradigms of philosophical aesthetics have still been dominated by the West. In light of Derrida's deconstructionism and Europe's postmodernism, philosophy-aesthetics in the sense of traditional rationalism, or early modern irrationalism which includes Western life aesthetics is derived from Logocentrism and Eurocentrism; but it fails to distill from the Other or East culture like Chinese classic philosophy-aesthetics. Western philosophy-aesthetics, with its obvious defects, easily falls prey to deconstruction and subversion; hence it was dislodged in debris under the attack of Western postmodernism in the twentieth century. Many Western philosophers think it important to assimilate Eastern wisdom to redeem or rebuild the future philosophy-aesthetics. For instance, Martin Heidegger, being influenced by Laozi’s Taoism, declares that we must step on the road. He states

...there is announced here a still unspoken gathering of the whole of Western fate, the gathering from which alone the Occident can go forth to meet the coming decisions - to become, perhaps and in a wholly other mode, a land of dawn, an Orient. (Heidegger, 1968, pp. 69-70)

This move is to get out of the crisis of metaphysics and philosophy. This is a turn to East. Derrida states clearly that deconstruction is first of all to deconstruct the dominant Western philosophical tradition and that it is of necessity to involve the Other as much as possible in the construction to which reference to Chinese wisdoms is of great significance (Du \& Zhang, 2003, pp. 46, 85). I am to affirm the great capacity of Chinese classic philosophy-aesthetics and analyze its global contribution from three aspects.

GU Zu-zhao, Professor in Department of Chinese Language and Literature at Anhui University, research interest is literary criticism and aesthetics. Email:gu-zuzhao@163.com. 


\section{Part I Laozi’s Interpretative Mode of Grandeur}

A number of issues have been left unresolved by Western philosophy. Firstly no conclusion has been made concerning the debate over monism, dualism or pluralism. Secondly, it seems hard to yield any definite view concerning whether we should comprehend the world in the way of rationalism, irrationalism, or life philosophy. Thirdly, no real winner emerged from the contention of traditional metaphysics, intuitional philosophy, experientialism and deconstructive postmodernism. It is obviously difficult to rebuild the metaphysic philosophy after postmodernity; and present deconstructionist and postmodern resources could no longer satisfy human souls longing for rationality and transcendence. China is another case. Modern Chinese have cultivated profound feelings toward Marxist philosophy but have their own bewilderment. For instance how to adhere to dialectic materialism while balancing certain positive elements of postmodern pluralist thinking? While one should hold firmly to the truth of Marxist epistemology, how to deal with its contradiction with relativism, agnosticism and nihilism in the West? Since Marxist dialectics cannot be forsaken, how could one absorb network thinking and system thinking besides opposing the mechanic and linear thinking? These are but a few examples of difficult academic tasks in the twenty first century (Gu, 2015, pp. 351-352). As stated above, Western thinkers have long wished to count on China or eastern wisdom to rid of their perplexities. Laozi's wisdom in China's philosophy offers a particularly sublime mode of interpretation which can solve key issues of logic. This mode is given in Part 42 of Laozi.

道生一, 一生二, 二生三, 三生万物。万物负阴而抱阳, 冲气以为和。

The Tao produced One,

One produced Two,

Two produced Three,

Three produced All things.

All things leave behind them the obscurity (out of which they have come), and go forward to embrace the Brightness (into which they have emerged) while they are harmonized by the breath of Vacancy. (Ren, 1985, p. 152)

The passage quoted here represents the outlook of Taoism towards universe and natural generation and their general approach to the world. With its inherent transcendental and inclusive nature, it can be seen as the most sublime interpretative mode. In comparison with Western philosophy, Taoism, as a multi-layered system, has the special capacity to transcend and absorb new elements. Taoism, based on life experience and aesthetical experience, is an organic body of philosophy and aesthetics. Given the truthful nature of life experience, notions and conclusions of Chinese philosophy are true to reality and self. Chinese understanding tends to transcend initial personal experience and yearns to observe the world for ultimate Tao, or way of being; hence Chinese philosophy could channel physics and metaphysics by following life principle which features the Harmonious beauty as poetic wisdom.

It certainly requires an academic monograph to expound the sublime interpretative mode framed by Laozi; hence his key views would be briefly stated here. First of all, in Laozi's view, the world is an existence with multiple layers, so is human understanding. The notion that Tao produced One affirms monism in the sense of dialectic materialism. Mao Zedong's view that one divides into two tends to emphasize the conflict of opposites while Yang Xianzhen argues to combine two into one which is harmony. Their views are compatible with dualism in the level that "One produced Two" which also justifies the existence of Marxist methodologymaterialistic dialectics Derrida may have his reasons to hold against binary opposition but his view is one-sided 
in the level that One produced Two. The level that Two produced three and Three produced all things is equally important. This level sustains human understanding on the monistic and dualistic basis; and "three" which means a great many, a multitude is a bridge between metaphysics and physics. Accordingly, perceptual and rational aspects or metaphysical and physical aspects are in good fusion. Human understanding towards physical essence evolves into a conceptual system, rather than a centralized truth. Vladimir Lenin seems to discern this point pretty early as he states to the effect that human thinking goes through from phenomenon to essence and delves from basic essence to primary essence, then into infinity and that truth could only emerge from physical totality and their mutual relations (Lenin, 1957, pp. 256, 181). Laozi’s interpretative mode, with its emphasis to multiple layers and their relations, accords with Lenin's perception and is compatible with Marxist philosophy in a profound way.

It should be noted that China's discovery of world as the multi-layered systems has been unknown to Westerners. Kantian notion of antinomy often puts questions at varying levels on the same surface. Though he discovers West had monistic, dualistic and triadic outlook of the world, Hegel only treats them on a static surface. Due to his lack of systematic awareness, he tends to comprehend the world in a monistic manner. In opposition to unifying description and logics of binary opposition, Derrida goes to another extreme without understanding the systematic nature of the world. His pluralism based on individual difference deconstructs traditional rationalism and ignores the multiple layers of the universe. Laozi's interpretative framework, with its due regard to universal diversity, takes in and transforms rational elements of deconstructionism and postmodern pluralism in the level that Three produced all things. Facing Western perplexity, Chinese philosophy demonstrates its comprehensive and transcendental nature. It is not exaggerated to state that China might be the only nation which offers such superb mode of interpretation and working plan.

How to understand this Chinese character "sheng” (生, produce or generate) is central to this interpretative mode; and this very word defines the Tao which sustains the endless cycling of the Heaven, the Earth and the Humanity. That "all things leave behind them the Obscurity (out of which they have come), and go forward to embrace the Brightness (into which they have emerged) while they are harmonized by the Breath of Vacancy" describes the universal law of life. Neo-Confucian thinkers all regard Chinese philosophy as life philosophy. Liang Shuming argues that Universe is a big life organism which sustains the evolution from living creatures to human society (2005, p. 87). Xiong Shili argues that we humans may know our life constitutes universe itself and cannot be isolated from universe and that all belong to one Great Life without the separation of inner from outer (1985, p. 535). Fang Dongmei also endorses the view that Chinese philosophy is life philosophy as he believes that there only exists one Great Life from Earth to Heaven. Humans live in great harmony with everything in the universe and bear sympathy to each other and coordinate with each object, thus forming the organic flow of life (1993, p. 211). In brief these thinkers all agree that Chinese philosophy is a construct based on life experience and aesthetic experience; so Chinese philosophy contains strong points of philosophy-aesthetics.

Chinese philosophy approaches the world in a feasible way; and that is the basic reason why it can deliver human philosophy from overall predicament. Tao which is the truth or the law pursued by human being is actually specific and realistic. Part 21 of Laozi which reads that

道之为物, 惟恍惟惚。惚兮恍兮, 其中有象; 恍兮惚兮, 其中有物; 窈兮冥兮, 其中有精, 其精甚真, 其中 有信。 


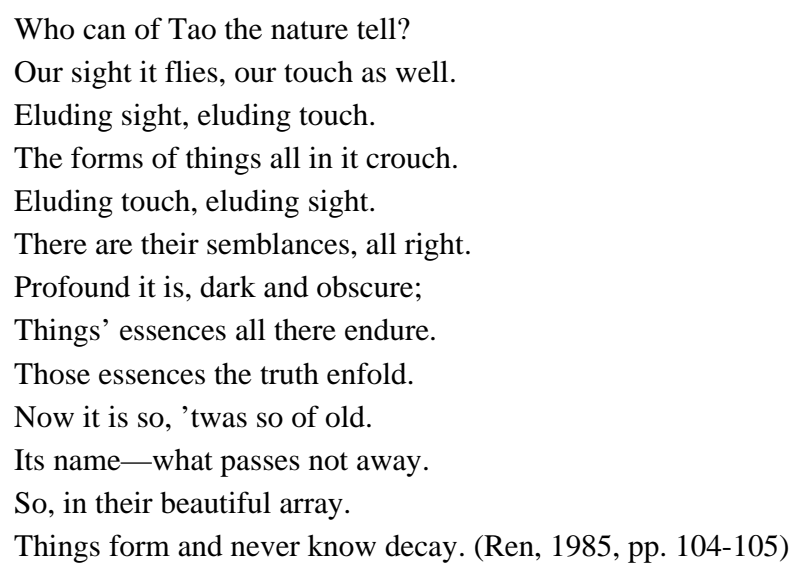

The passage quoted here demonstrates that perceptual experience from personal perception to rational thinking stays in the form of feelings. "Our sight it flies, our touch as well" shows that such perception haunts the mind; and it does contain "semblances" and real "things" which "form and never know decay." Since its grasp of the world is firmly grounded in true life experience, the notions and conclusions of Chinese philosophy and aesthetics can go beyond temporal-spatial limits and be subject to verification of various nations. Laozi's interpretative mode, with its true and down-to-earth quality, represents the most significant contribution of Chinese philosophy to the world.

The American scholar Filmer S. C. Northrop seems aware of such difference. He argues that philosophical notions are either obtained by intuition or by postulate. Notions in the former category are wholly defined by the direct perception of this object. For instance, the notion "blue" is the direct perception of the blue color. Postulated notions, together with certain outlook, constitute another system; and their meanings are defined by the deduction of the logic system (Northrop, 1946, p. 187). The intension and extension of each notion is strictly contained by self-consistent logics which gives the special meaning to each concept and notion; and this makes such postulated theoretical system a highly subjective self-closure. Western philosophy and aesthetics, constructed in this way, is the product of logo-centrism. For the same reason formal logic is not totally reliable since it can either deduct the truth from actual state of things or turn the mistake into truth. Hegel's thinking system often overturns subjective things with objective ones; and his view that art comes to its demise is a pseudo-proposition or a fallacy caused by logo-centrism and grand narrative. The postmodern attack on grand narrative by deconstructionism is to certain degree justifiable. Hence Northrop thinks that Chinese philosophy-aesthetics is supplementary with its Western counterpart. For instance, "life principle”, "beauty as the embodiment of moral judgment" or "moral law" are notions raised by Kant who fails to have a deeper argument (Kant, 1993, pp. 159-201, 117-118); but their rich content are explored by Chinese philosophy. Laozi's interpretative mode, with its realistic quality and comprehensive character, is the greatest contribution of Chinese philosophy to the world.

\section{Part 2 Aesthetic Secrets Revealed by Zhuangzi and Taoism}

Zhuangzi, as the theoretical successor of Laozi's thinking, makes far more important contribution to Taoist aesthetics. He defines Tao as the "Great beauty" and unifies life experience and aesthetical experience into organic whole, laying the foundation of aesthetical experience for Chinese philosophy.

“Knowledge Wandered North” in Zhuangzi (知北游·庄子) says: 
天地有大美而不言, 四时有明法而不议，万物有成理而不说。圣人者，原天地之美，而达万物之理。是故， 至人无为, 大圣不作，观于天地之谓也。

Heaven and Earth have their great beauties but do not speak of them; the four seasons have their clear-marked regularity but do not discuss it; and the ten thousand things have their principles of growth but do not expound them. The Sage seeks out the beauties of Heaven and Earth and masters the principles of the ten thousand things. Thus it is that the Perfect Man does not act, the Great Sage does not move - they have perceived [the way of]Heaven and Earth, we may say. (Yang, 1991, p. 429)

Zhuangzi deepens Laozi's views on system and state of affairs and writes such famous essay as "Autumn Floods" and believes that "beauty" is a layered existence. "Great beauty" is the highest state of beauty which can only be perceived by "the Sage" and "Perfect Man"; thus this view is interlinked with Kant's notion of beauty as the embodiment of morality. The contribution of Zhuangzi to human aesthetics is far more significant than that of Kant.

Firstly, Zhuangzi's view of "Great Beauty” falls into philosophical category. In the above quotation, the "regularity" of "four seasons" and "the principles" of things come from the observation and thinking of the sage. These are what Laozi says "Tao". In the domain of Chinese philosophy, Tao as a metaphysical concept is the aesthetical object, which may not be admitted by Western aesthetics. Though he is vaguely aware that poetry,

...invigorates the mind by letting it feel its faculty — free, spontaneous, and independent of determination by nature of regarding and estimating nature as phenomenon in the light of aspects which nature of itself does not afford us un experience, either for sense or understanding, and of employing it accordingly in behalf of, and as a sort of schema for, the supersensible. (Kant, 1979, p. 401)

Kant tends to understand beauty only in the limited perceptual sense, which makes his aesthetic notions rather contradictory. That philosophical idea can be regarded as a kind of beauty is a significant notion in Chinese philosophy; and Zhuang zi’s view is typical of Confucian and Taoist views in the pre-Qin period.

Secondly, since there exists such aesthetic link between Sage and "Universe", how does beauty come about? Zhuangzi's interpretation is certainly visionary. For one thing, as early as three century B.C. he describes the appreciation process of humanity towards nature as an interactive, joyful and sympathetic dialogue on an equal footing. For another such mutual dynamism, rooted in life principle from Laozi's theories, means life activity in the broadest sense. All aesthetic secrets can be revealed by exposing the soul and agency of life. "Haven and earth were born at the same time I was, and the ten thousand things are one with me." Zhuangzi views aesthetic activity as the life activity in the broadest sense; and only by grasping the soul and agency of life can we reveal all aesthetic secrets. In the third place, it is true that "Heaven and Earth have their great beauties but do not speak of them"; but humanity can come and go alone with the pure spirit of Heaven and earth without viewing the ten thousand things with arrogant eyes (Yang, 1991, p. 715). This "come and go" means that this kind of communications and dialogue with spirits on an equal footing can trigger the birth of beauty. It is a pity that many Western thinkers fail to understand this point. Great figures like Kant, Hegel and Heidegger believe that aesthetics means to appreciate certain objects and that aesthetical appreciation is one-way psychological behavior. That is why it is hard for them to reveal the nature of beauty.

Thirdly, Zhuangzi's notion of equality and love-all view accounts for the happenstance of beauty. Western aesthetics fails to recognize the interactive nature of aesthetics because its system is confined in scope in regarding human being as the supreme creature of the Universe. Chinese Confucian notion of benevolence is 
often restricted to human beings and advocates universal brotherhood. Zhuangzi in Taoist School says, "Let love embrace the ten thousand things; heaven and earth are a single body.” (泛爱万物, 天地一体也。) ${ }^{1}$ Beauty springs out from such boundless love which is the foundation of Zhuangzi's aesthetic theory. Beauty emerges spontaneously when the human full of love for life has the spiritual interaction with all things. The mutual admiration and respect of one life for the other is caused directly by the instinct of love for life. ${ }^{2}$ Kant has a slight touch of this point by claiming that "FAVOR is the only free liking” (1981, p. 360). Such favor occurs between equal entities without purpose or benefits; and it needs not distance or empathy but is realized through the interchange of free life. Zong Baihua points out that a sense of beauty is born on the come and go of free spirit of objects (1994, p. 349). Zhuangzi's aesthetic view so perfectly expounds Kantian notion of beauty as freedom that the latter should have been surprised by an answer which happened more than two thousand years ago.

Fourthly, in view of Zhuangzi, beauty refers to a state of being in which subject and object are harmonized into one. The state in which Zhuangzi (Chuang Chou) dreamed of a butterfly may explains his prototype of beauty.

昔者庄周梦为蝴蝶, 栩栩然蝴蝶也, 自喻适志与 ! ……不知周之梦为蝴蝶与, 蝴蝶之梦为周与? 周与蝴蝶, 则必有分矣。此之谓 “物化”。

Once Chuang Chou dreamt he was a butterfly, a butterfly flitting and fluttering around, happy with himself and doing as he pleased. He didn't know he was Chuang Chou. Suddenly he woke up and there he was, solid and unmistakable Chuang Chou. But he didn't know if he was Chuang Chou who had dreamt he was a butterfly, or a butterfly dreaming he was Chuang Chou. Between Chuang Chow and a butterfly there must be some distinction. This is called the Transformation of things. (Chen, 1994, p. 92)

Xin Qiji says in "Congratulating the Bridegroom”: I find green mountains so charming and vice versa. Li Bai says in a poem that "we gaze at each other, neither growing tired. There is only Jingtingshan” (Wu, 1996, p. 164). The Qing poet Li Fu has a similar verse. "Rejoicing in mutual gaze, singing over a fishing boat, we find the grass light shining at night.” The renowned scholar Zong Baihua distills from these famous poems in Chinese classical culture a central aesthetic notion which has, however, been improperly ignored by modern Chinese aesthetic studies. Only until the twentieth century after Western inter-subjective aesthetics emerged did we find Zhuangzi's aesthetics outlook so transcendental, so profound yet delicate and original that it is of theoretical significance. The rebuilding of philosophy-aesthetics in the future would be impossible without the contribution of Zhuangzi’s philosophy-aesthetic thinking.

\section{Part 3 Philosophical Beauty as a Confucian Concept}

The above argument of Zhuangzi's aesthetic thinking has presented the Taoist aesthetic outlook that philosophical principle can be treated aesthetically, which is more of a Confucian aesthetic tradition. Mencius who was contemporary with Zhuangzi proposes the notion of philosophical beauty a bit earlier. In Gaozi I, Mencius says,

口之于味，有同嗜焉；耳之于声，有同听焉；目之于色，有同美焉。至于心，独无所同然乎？心之所同然者 何也? 谓理也, 义也。圣人先得我心之所同然耳。故理义之悦我心, 犹雉䅈之悦我口。

\footnotetext{
1 This is actually the view of Huishi which is also approved by Zhuangzi.

2 The love for life springing from instinct is conditional. Human beings need to throw light of love on everything before everything else projects back benevolence, thus bringing out the beauty from mutual attraction. Not all living creatures can send for the message of love, such as Crocodile or toads, as Hegel names.
} 
Men's mouths agree in having the same relishes; their ears agree in enjoying the same sounds; their eyes agree in recognizing the same beauty — shall their minds alone without that which the similarly approve? What is it then of which they similarly approve? It is, I say, the principle of our nature, and the determinations of righteousness. The Sages only apprehended before me that of which my mind approves along with other men. Therefore the principles of our nature and the determination of righteousness are agreeable to my mind, just as the flesh of grass and grain-fed animals is agreeable to my mouth. (Zhu, 1931, Vol. 6)

In this passage Mencius consciously expounds the philosophical beauty from an aesthetic perspective. In his view, the beauty of principle is as appealing to the mind of sage as that of the sound, color and taste to the body. But "the principles of our nature and the determination of righteousness", as the beauty of higher level, cannot be approached by the ordinary folk. It should be noted that Mencius's arguing does not come from nowhere and that he elevates the previous sage into a higher theoretic level. Hereby is an example of Confucius. An interesting discussion is recorded in Li Lou (I) of Mencius (孟子.离娄上). It can reveal the aesthetic tradition of Confucianism and its influence.

有孺子歌曰: “沧浪之水清兮, 可以濯我紧; 沧浪之水浊兮, 可以濯我足。” 孔子曰: “小子听之, 清斯濯 缨, 浊斯濯足矣, 自取之也。”夫人必自侮, 然后人侮之; 家必自毁, 而后人毁之; 国必自伐, 而后人伐之。《太 甲》曰: “天作擎, 犹可违, 自作㧛, 不可活。”此之谓也。

There was a boy singing, "When the water of the Cang Lang is clear, it does to wash the strings of my cap; when the water of the Cang Lang is muddy, it does to wash my feet." Confucius said: "Hear what he sings, my boys, when clear, then he will wash his cap-strings, and when muddy, he will wash his feet with it. This different application is brought by the water on itself. A man must first despise himself, and then others will despise him. A family must first destroy itself, and then others will destroy it. A State must first smite itself, and then others will smite it. This is illustrated in the passage of Tai Jia, "When Heaven sends down calamities, it is still possible to escape them. When we occasion the calamities ourselves, it is not possible any longer to live.” (Zhu, 1931, Vol.4)

Confucius draws from a child's ballad that one has to take full blame for his faults; and Mencius who is inspired by this connects the philosophical principle with the way to cultivate oneself, to regulate the family and govern the nation. The passage “Gong Sun Chou” in Mencius (孟子·公孙丑) has the similar reasoning. In the view of Confucius, the poem "Chi Xiao” in Book of Songs (诗经·鸱鸮) means the way to protect the state, on which basis Mencius makes further inference. The tutor-disciple way of interpretation in Mencius is not accidental but a Confucian tradition to read the folk ballads in Book of Songs in a deep way for philosophical meaning. The mode to appreciate Book of Songs appeared as early as in The Analects of Confucius.

\footnotetext{
子夏问曰: “巧笑倩兮, 美目盼兮, 素以为绚兮。，何谓也？”子曰: “绘事后素”。曰: “礼后乎? ” 子曰: “起予者, 商也! 始可与言《诗》已矣。”

Tsze-hsiâ (Zi Xia) asked, saying, "What is the meaning of the passage- 'The pretty dimples of her artful smile! The well-defined black and white of her eye! The plain ground for the colors?'”

The Master said, "The business of laying on the colors follows (the preparation of) the plain ground."

"Ceremonies then are a subsequent thing?” The Master said, "It is Shang who can bring out my meaning. Now I can begin to talk about the odes with him”. (Yang, 1989, p. 309)
}

The poem “The Duke's Bride” (硕人) is but a lyric poem which eulogizes the charm and beauty of the daughter of Lord Qi and the wife of Lord Wei. The stanza quoted by Confucius and his disciple describes the lady's appearance; but they infer from this poem that refinement can only be made on the good basis. Zi Xia, not surprised at all, is very much ready to rethink the conclusion of Confucius at the level of ritual and benevolence. Zi Xia's thinking goes beyond his teacher and thinks that benevolence comes before rituals, of 
which Confucius speaks highly. He says: "Bushang, your view is inspiring to me. We can discuss The Book of Songs together." Another example to read The Book of Songs in the same way can also be found in the passage “Hsio R” (学而) of the Analects of Confucius.

\footnotetext{
子贡曰: “贫而无谄，富而不骄，何如？” 子曰: “可也。未若贫而乐，富而好礼者也。”子贡曰: “《诗》 云： ‘如切如群, 如琢如磨。” 其斯之谓与? ” 子曰: “赐也, 始可与言《诗》已矣! 告诸往而知来者。”

Tsze-kung (Zi Gong) said, "What do you pronounce concerning the poor man who yet does not flatter, and the rich man who is not proud?” The Master replied, “They will do; but they are not equal to him, who, though poor, is yet cheerful, and to him, who, though rich, loves the rules of propriety.” Tsze-kung replied, "It is said in the Book of Poetry, 'As you cut and then file, as you carve and then polish.'-The meaning is the same, I apprehend, as that which you have just expressed.” The Master said, "With one like Ts'ze, I can begin to talk about the odes. I told him one point, and he knew its proper sequence”. (Yang, 1989, p. 305)
}

To understand this dialogue one needs to consider the original meaning of the sentence "As you cut and then file, as you carve and then polish”, which comes from the poem of "Qi Yu” (The River Flows past, 卫 风.淇澳). The ballad originally describes the bearing and charm of a young gentleman. In the eyes of a girl, this young gentleman, with high literary talent, has a physical build as perfect as a carved statue, with complexion like polished jade. Confucius did not pay much attention to the whole poem but only to interpret this poem as the rigorous self-cultivation of a true gentleman. Zi Gong, from the higher level of Confucian rituals, thinks that these two sentences symbolize the noble livelihood and ideal virtues which go beyond the level of personal possession. From this instance, one can see that $\mathrm{Zi}$ is that intelligent student who is capable of telling the future by knowing the pas and that his interpretation is superior to that of Confucius. The above two instances show that for Confucius, the ability to read The Book of Songs philosophically is a prerequisite for dialogue between Confucius and his disciples. In a sense, The Book of Songs can be seen as the embodiment of philosophical principles. In a way, with the poetic backdrop of music and dance, the way to rule the nation and the ideal way of human relation can be appreciated aesthetically. Three hundred poems in The Book of Songs have been tuned with various instruments and Confucius is intoxicated with the appeal of philosophical principles amid the orchestral music. In the view of Zhu Xi only the power of supreme principles can reach the mind of the Sage (Zhu, 1931, Vol. 4). He also describes the state of mind which generates such philosophical beauty. He says to the effect that if one applies the clear principle to its full, the power and beauty of the principle can be articulated and reach everywhere (Chen, 2003, p. 504). Zhu argues that moral principles have the appeal of spiritual wisdom and reach the state of self-transcendence. The tradition to discover the Tao by observing the common things began as early as Southern and Northern Dynasties. This state is called by Zong Bing the painter from that period “Cheng Huai Wei Xiang” or “Cheng Huai Guan Dao” (Wu, 1994, pp. 357, 359). The two terms mean that one needs to remain free from social constraints to reach a state of spiritual lucidity. Hence Chinese aesthetic outlook has been established, which means philosophical beauty is possible.

Thanks to such aesthetic tradition, there emerged in Chinese literary history several waves of poetic movement with focus on philosophical principle. There has been the poetry of moral persuasion in the Han Dynasty, the metaphysical poetry in the Wei and Jing Dynasties, the Buddhist poetry of the Tang Dynasty, the Taoist poetry of the Song Dynasty and subsequent classical poetry movement in the Ming and Qing. Many famous views have been left. “Canon of Yao” of Book of Documents (尚书尧典) states that “The Poem articulates what is on the mind intently” (“诗言志”). The Book of Xunzi points that "ritual dances convey the way of the Universe” (“舞意天道兼”). Liu Xie believes that “one needs to draw on literary text to articulate the 
way of being” (因文而明道). Figures like Han Yu and Liu Zong-yuan argue that literary texts are used to clarify the way of being (文以明道) while Zhou Dun-yi calls to use literature to express the way of being (文以 载道). Zhu Xi argues to use things to articulate the way of being (“借物明道”). Su Shi argues to use unconventional poetic images to express the philosophical principle (诗以反常合道为趣). Zhen De-xiu argues that poetic comparison and affective images can be adopted to articulate the principle in the mind of sages. Many aesthetic concepts such as mindset (“思致”), thematic principle (“理趣”) and sense flavor (“意味”) can also show the undeniable poetic and theoretic tradition focusing on philosophical beauty.

Chinese aesthetic tradition has been confined to the viewpoint of sentimentalism; so the existence and the value of its philosophical dimension have been seriously smothered by the study of ancient Chinese literary history. Since May Fourth under the influence of Western "perceptual-emotional" aesthetic outlook, the long-standing philosophical aesthetic tradition of China and its literary texts and theoretic materials have been ignored and buried in oblivion, seeming to have no chances of being revived.

Fortunately, this situation has been changed due to two events in the Western philosophical aesthetics in the twentieth century, which came to verify Chinese poetic tradition of Confucian philosophy and its great contribution to the world. Of these two events, one is the attack of Western modernist literature, the other is the attack of postmodern pluralism.

The modernist literary movement shows the distinctive philosophical tendency. T. S. Eliot argues that the truest philosophy is the best material of the greatest poet; and the position of a poet depends on how the philosophical principle is delivered by his poetry (Fu, 1986, p. 15). The French symbolist poet Paul Valéry points out that a poet has his abstract mindset, or his own poetic philosophy and that his metaphysical logic works in his poetic creation (Wu, 1983, p. 37). Gadamer says that modernism is hidden in abstruse symbolic signs and that philosophical thinking makes them objects of articulation, which in my eyes is the only reliable mode (Wu \& Hu, 1987, pp. 599, 592). Modernist literary movement with its distinct philosophical tendency and new aesthetic standards sweeps through the twentieth century. However, when the rise of postmodernism makes modernism a thing of the past, Western theoreticians fail to distinguish the modernist thinking from the previous and subsequent one and fail to understand its aesthetic significance in the context of Western culture. When Western modernism was introduced into China, I found instantly that Western modernism has nothing new but is surprisingly similar to Chinese aesthetic tradition with a focus on philosophical beauty (Gu, 1990). For one thing both are an escape from emotion. T. S. Eliot says: "Poetry is not a turning loose of emotion, but an escape from emotions" (Wu \& Hu, 1987, p. 47). Shao Yong believes that those poets who fail to discuss the universal principle tend to write poems indulged in emotions. Shao also disapproves of poetic sentimentalism. For another both resort to symbolic signs for main expression (2013, p. 3). Gadamer believes that symbols are what poets use to rediscover certain things; and his symbols refer to images with symbolic meanings. These are called the images of concepts to the mind in Book of Changes or conceptual images in Wang Cong's Lun Heng, or symbolic objects. In the passage “Tsze Han” in Confucian Analects (论语·子罕), the Master standing by a stream, said, "it passes on just like this, not ceasing day or night.” This flowing stream symbolizes the Tao which Confucius comes to comprehend; it means that everything exists in the one-dimensional temporality and absolute changes. Confucius is excited with such discovery of way of being which is certainly a "great beauty". Hence it can be concluded that symbolic images are an aesthetic medium of philosophical beauty and that Western modernist arts begins with symbolism. Thirdly, both prefer the unconventional style. Eugene Ionesco thinks that since modern people all behave in a very absurd way, unusual objects should be used to express the 
absurdity of human existence (Wu, 1983, pp. 351, 353). It should be noted that Chinese poets in the Tang and Song had been much conscious of weird style. For instance Du Mu is attracted by the appeal of Li He's weird and uncanny style. Su Shi and Liu Dao-chun argue for the weird and the uncanny, which is the forerunner of Western absurd theater.

The similarities between Chinese aesthetic tradition and Western modernism and their mutual responsiveness show that the occurrences of two are not accidental, but a regular and logic existence. The philosophy-aesthetic outlook of Chinese literature and its theoretic value is of global significance.

First of all, China as the "Other" has come to verify the philosophical beauty which Western modernists pursued is a logic existence. Western scholars should do more careful research about modernism in a way like they do on realism and romanticism so as to unearth modernist from the muddy sentimentalism. In the same way with the presence of the Western modernists as the Other, the philosophical outlook of Chinese literature which has long been neglected deserves to be revived. Accordingly, it is of necessity to reconstruct the literary and aesthetic history after Liu Xie's sentimentalism theory. Such rebuilding also holds true of West.

In the second place, the establishment of philosophical literature and philosophical beauty makes the monistic nature of literary and aesthetic phenomena questionable. It should be noted that there exists not only the philosophical beauty of conceptual images but also the historical beauty of phenomenon and truth as emphasized by realism and the perceptual-emotional beauty stressed by sentimentalism. If the triadic structure of beauty can be recognized, Laozi's interpretative mode that Three produced All things can be fully applied to literary studies and aesthetics. Accordingly the three artistic types in Hegel's Aesthetics can be properly inherited on the one hand; and the rational pluralistic and diverse elements of the postmodernism can be assimilated into literary theory and aesthetics. Under such context, the one-sidedness of Western philosophy since Baumgarten has been exposed; so the overall structure of literary criticism and aesthetic system in both China and the West has to undergo a thorough transformation.

In the third place, monistic logic of linearity, since the existence of philosophical beauty was often denied or ignored, fails to account for aesthetics and literature due to its theoretic loopholes. For instance Kant argues

...whether we are dealing with beauty of nature or beauty of art, we may make the universal statement: That is beautiful which pleases in the mere estimate of it (not in sensation or by means of a concept. (Kant, 1993, p. 152)

But his view that beauty is the symbol of morality or "a sort of schema for, the supersensible" break the former view into pieces. By making up Kant's view, Hegel distinguishes three basic categories of art, namely, symbolic, classical, and romantic, thus building the triadic and diverse nature of beauty. But he defines beauty as the perceptual realization of concept from the classic viewpoint and refuses to recognize other types, such as philosophical beauty, which also results from monism (Zhu, 1990, p. 137). Modernist figures from Eliot to Gadamer are monistic hardliner of philosophical beauty. Just Chinese scholar Jiang Kongyang points out, the whole aesthetic study is stuck in the blind alley of monism (2005, p. 656). It is obvious that such mutual verification between China and Western aesthetics may help to free aesthetic study from the narrow monistic perspective.

Such "freedom" contains two levels of academic elements.

One means to deepen the understanding of literature and art and aesthetics. For instance medical science might be shallow if it only knows "humans" since its knowledge of human is not enough to cure many diseases. The division of humanity into men and women would be much better; but the triadic structure from men, 
women and children could produce more profound knowledge of human being which will ensure the correct diagnosis. Our knowledge towards literature and art and aesthetics, though being summarized on the basis of monism and dualism, tends to be shallow and inaccurate. The significance of the level "Three produced all things" is still not properly recognized; hence the triadic and diverse thinking about aesthetics prompted by Chinese philosophy-aesthetic tradition means the epistemological transformation of human literature and aesthetics.

The other means to deepen the understanding of the self-regulation of literature and art and aesthetic development which at present is still at the level of social determinism and simplistic contextualism. Just as Liu Xie says, the texture and style of songs and ballads go with the actual times; and the up and down of literature depends on temporal and social sequence (1982, pp. 311-331). The literary critical theory of the former Soviet Union and traditional Western literary theory did not move far from such contextual view while vulgar social studies is even worse. It seems that, from such theories, literature and art do not have their internal elements and dynamics for their own development. Once established, triadic structure of aesthetics is not accidental but linked with three basic types of human spiritual needs. German classical aesthetics holds the view that human spiritual needs fall into cognitive, emotional and conceptual categories, which corresponds to three aesthetic types. They are sensuous-emotional beauty, image-philosophical beauty and phenomenon-truth (historical) beauty, which can also be connected with sentimentalism, realism and symbolism in art. The Qing scholar Ye Xie thinks that the world exist philosophically in "principle, event and circumstance" and develops this view to the perfection of principle, event and circumstance in art and literature (Guo, 1980, pp. 346, 353-354). It is obvious that his view bears certain affinity with that of German classic aesthetics. Three basic types of aesthetics controlled by human spiritual needs confirm Laozi's triadic theory of aesthetics on the one hand and show that the specific artistic modes depend on both social elements and internal human desire. Art in each age all manifests itself in the state of synchronicity but shows a tendency different from the previous times. Though each aesthetic wave claims its originality, it is but connected with certain aesthetic mode in the past though different in artistic forms. For instance, most critics hold that Western modernists, upon their debut, consciously broke away from traditional Western art (Abrams, 1990, p. 195). But judging by Hegel's Aesthetics, modernist art is but a modern version of primitive symbolic art highlighting philosophical beauty. Postmodern art which claims to be avant-garde or counter-art does not go out of the bounds of human needs. Its call of "no depth" means to refuse to accept the philosophical beauty of modernists. Allen Ginsberg's Howl is still an outcry of emotions, a cry more uncouth and spontaneous than traditional lyric beauty.

The reason why the future of literature and art only develops within the triadic circle of "sense-emotion-concept" is the self-regulation of artistic development. The future development of art prompted by the aesthetic ideal resulting from diverse human spiritual needs of various ages still has to learn from the past artistic types. Such self-regulation of literature and art is much deeper than "literariness" of Russian formalism. The discovery and argument of Mencius towards philosophical beauty is a contribution of global significance.

It should be noted that the contribution of Chinese ancient aesthetics is more than three points presented here. China as the Other is of great significance to the building of Western and global philosophy-aesthetics.

\section{References}

Abrams, M. H. (1990). A Glossary of Literary Terms. (Zhu Jinpeng et al., Trans.). Beijing: Beijing University Press. 
Chen, Guying. (1994). Discussion on Making All Things Equal. In The Annotated Interpretation of Zhuangzi. Beijing: Zhonghua Book Company.

Chen, Liangyun. (Ed.). (2003). Zhuzi Yulei. In The Selected Works on Ancient Chinese Essay Study. Nanchang: Baihuazhou Literature and Art Press.

Du, Xiaozhen, \& Zhang, Ning. (Eds). (2003). The Speech Collection of Derrida in China. Beijing: Central Compilation and Translation Press.

Eugene Ionesco. (1983). The Starting Point. In The Selected Works of Modern Western Literary Criticism. Shanghai: Translation Publishing House.

Fang, Dongmei. (1993). “Chinese Outlook on Life” Fang Dongmei’s Works. Beijing: Qunyan Press.

Fang, Guowu. (Ed). (2015). Art without End: The Collection of Gu Zuzhao’s Academic Thinking Symposium. Hefei: Anhui Renmin Press.

Fu, Xiaoxian. (1986). Random Talk on Western Literature. Beijing: China Friendship Publishing Company.

Gu, Zuzhao. (2015). “Three Basic Modes of Human Artistic Realm”. In Fang Guowu (ed.), Art without End: The Collection of Gu Zuzhao's Academic Thinking Symposium. Hefei: Anhui Renmin Press.

Guo, Shaoyu, \& Wang Wensheng. (Eds). (1980). The Anthology of Ancient Chinese Literary Criticism (Vol. 3). Shanghai: Guji Press.

Heidegger, Martin. (1968). What is Called Thinking? (J. Glenn Gray, Trans.). New York: Harper Row.

Jiang, Kongyang. (2005). My Writing of New Aesthetics. In The Complete Works of Jiang Kongyang (Vol. 5). Hefei: Anhui Education Press.

Kant, Immanuel. (1993). The Critique of Judgment. (Zong Baihua and Wei Zuoming, Trans.). Beijing: Commercial Press. (Section 53, Western Aesthetics History. (Zhu Guangqian, Trans.). (1979). Beijing: People’s Literature Publishing House.)

Lenin, Vladimir. (1957). Philosophy Notes. Beijing: Renmin Press.

Liang, Shuming. (2005). Zhaohua (Morning Talk). Tianjing: Baihua Literature and Arts Press.

Liu, Xie. (1982). “Wuse of Wenxin Diaolong” Annotated Translation of Wenxin Diaolong (Vol. 2). Lu Kanru \& Mou Shijin, (Eds.). Jinan: Qilu Press.

Northrop, Filmer S. C. (1946). The Complementary Emphases of Eastern Intuition Philosophy and Western Scientific Philosophy. In C. A. Moor (Ed.), Philosophy, East and West. Princeton: Princeton University Press.

Ren, Jiyu. (1985). Laozi: A New Interpretation. (James Legge, Trans.). Shanghai: Guji Publishing House.

Shao, Yong. (2013). Preface. In Yichuan Jizhang Ji. Beijing: Zhonghua Book Company.

Wu, Gongzheng. (1994). "Preface to Landscape Painting” and “The Biography of Zong Bing”. In The Aesthetics History of the Six Dynasties. Nanjing: Jiangsu Fine Arts Press.

Wu, Lifu, (Ed.). (1983). Paul Valéry. "Poetry and Abstract Mind”. (Feng Huazhan, Trans.). In The Selected Reading of Modern Western Critical Theory. Shanghai: Shanghai Translation Publishing House.

Wu, Lifu, \& Hu, Jingzhi. (Ed.). (1987). “Art as Festive” (by Gadamer). “Tradition and Individual Talent” (by T. S. Eliot, Mo Zelan and Deng Xiaoyun, Trans.). In Selected Anthology of Western Literary Theoretic Works. Beijing: Beijing University Press.

Wu, Mei. (1996). The General Survey of Lyric Studies. Shanghai: East China Normal University Press.

Xiong, Shili. (1985). New Cittamatra. Beijing: Zhonghua Book Company.

Yang, Bojun. (1989). Vernacular Interpretation of Four Books. Changsha: Yuelu Publishing House.

Yang, Liuqiao. (1991). The Annotated Intepretation of Zhuangzi. (Burton Watson, Trans.). Shanghai: Shanghai Guji Press.

Zhu, Guangqian. (1990). Hegel Aesthetics. In The Complete Works of Zhu Guangqian (Vol. 13). Hefei: Anhui Education Press.

Zhu, Xi. (1931). Annotated Four Books (6 Vols.). Shanghai: Changwen Bookshop.

Zong, Baihua. (1994). On the Lucidity and Fullness of Literature and Art. In The Complete Works of Zong Baihua (Vol. 2). Hefei: Anhui Education Press. (Originally published at Literature \& Art Monthly, May, 1943.) 